\title{
KLASSEBEVIDSTHED OG KONJUNKTURCYKLUS? ${ }^{1}$
}

\section{Peter Brückner}

Barbara Sichtermann

Den efterfølgende artikel er ikke videnskab - i hvert fald ikke, hvis man skal tro den tyske forbundsdomstol. Ud fra Brückners orientering mod den individuelle og kollektive handlen og dens betingelser, har den tyske forbundsdomstol officielt afgrænset et kontemplativt eller betragtende videnskabsbegreb. Alt, hvad der falder uden for dette, må ikke doceres ved de tyske universiteter: så snart man beskæftiger sig med en handlingsorienteret samfundsanalyse, er man uvidenskabelig. Af denne grund er omkring halvdelen af Brückners produktion forbudt litteratur i tyske universitetsuddannelser. - Den foreliggende artikel er også uvidenskabelig, fordi den diskuterer klassebevidsthed ud fra et standpunkt, hvor den aktive individuelle handlen i en kollektiv ramme står i centrum.

1. Bearbejdet udgave af et foredrag, som en af forfatterne, Peter Brückner, har holdt 21.3.75 i København. 


\section{Fem teser om »klassebevidsthedens« særlige placering i den materialistiske teori:}

1. Klassebevidsthed er ikke en kategori, der tilhører teorien (i snævrere forstand), den viser hen til materialistisk empiri ${ }^{2}$. Kritikken af den politiske $\varnothing$ konomis kategorier udfolder sig på grundlag af kritikken af det borgerlige samfunds produktionssammenhæng (arbejdsdeling, vareform, den menneskelige arbejdskrafts vareform, værdi og merværdi, tingsliggørelse, værdiens værdiøgning af sig selv). Materialistisk empiri fremkommer i orienteringen mod brugsværdier, mod producenternes behov, ${ }^{3}$ og har selv en brugsværdi. Den udspringer i konkrete livssituationer (arbejde, dagligliv).

2. Det er ikke krisen, der er kilden til »klassebevidsthed«, ikke længere kun det kapitalistiske systems manglende evne til at fungere i overensstemmelse med sine egne prioriteringer, men langt snarere også den omstændighed, at kapitalen (og de afhængige politiske systemer) lader behov og kritiske potentialer opstå, der modvirker dens egen reproduktion. ${ }^{4}$ For så vidt implicerer et materialistisk begreb om organisation også en orientering mod »brugsværdier« og behov, herunder disses handlings-, tænke-, erfarings- og fantasikvaliteter.

3. Klassebevidsthed er ikke blot noget kognitivt, ikke blot et spørgsmål om en forstand, der gennemskuer noget. Den opfattelse, at klassebevidsthed primært er en bevidsthedsform, en »erkendelses«-form med rationel struktur, ligger selv under for den adskillelse af fornuft og sanselighed, som er opstået i og med det borgerlige samfunds tilblivelsesproces. Ved denne adskillelse rives sammenfletningen af fornuft og revolution historisk set fra hinanden; i klassebevidstheden bliver denne adskillelse nemlig netop ophævet.

Det borgerlige rationalitetsprincip (og pædagogikkens dominans - som en rest fra oplysningstiden f.eks. i arbejderbevægelsens partier) hænger sammen med værdiabstraktionens, det »kvantitatives « herredømme, med ideen om den universelle mulighed for at skabe historien (... Idee der universalen Machbarkeit der Geschichte) (og ideen om »effektivitet «). Borgerlig rationalitet sætter sig i denne forstand ikke blot igennem via de $\varnothing$ konomiske forholds stumme tvang og/eller ikke- $\varnothing$ konomisk tvangsmagt. ${ }^{5}$ For at det borgerlige samfunds institutioner skal kunne fungere, må moralske og kulturelle normer, som

2. Jfr. F. CERUTTI o.a., Geschichte und Klassenbewusstsein heute. Amsterdam, Schwarze Reihe nr. 12, 1971.

3. Altså mod samfundsmæssige områder, som det ikke er muligt »at subsumere reelt«, mod de »ikke-kumulative processer«i H. LEFEBVRE's forstand.

4. Jfr. H. GINTIS, Zur Dialektik der Bewusstwerdung im Spätkapitalismus. Merve Verlag, Berlin, 1974 (forord: André Gorz).

5. Jfr. A. KROVOZA, Die Verinnerlichung der Normen abstrakter Arbeit und das Schicksal der Sinnlichkeit, i: Das Unvermögen der Realitet osv., Berlin, 1974 (Reihe »Politik«nr. 55). 
trænger ind i den enkeltes hele psykiske udvikling, sætte sig igennem hos både borgeren og arbejderen. Den loyalitet, der således dannes i masserne, har en erfaringsside og en handlingsside. Klassebevidsthed, som bryder med den loyalitet, er også af den grund ikke et blot og bart bevidsthedsanliggende: den åbner for ændrede erfaringsmuligheder og handlingsalternativer ${ }^{6}$.

4. Klassebevidsthed er ikke blot en subjektiv genspejling af objektive, dvs. $\varnothing$ konomiske betingelser, der er mere eller mindre »modne« til omvæltning. I klassebevidstheden bliver det derimod muligt at erfare nutiden som en historie, som vi kan forme, nutiden er ikke kun produkt af kapitalens historie. I klassebevidstheden begynder omvendingen af forholdet mellem økonomi og bevidsthed ${ }^{7}$.

5. Klassebevidsthed er hverken et empirisk kontrollerbart »indhold « hos det enkelte empiriske individ (den falder dermed uden for den logiske empirismes og positivismes indsnævrede empiri-begreb), ejheller en overempirisk, dvs. aldrig virkelig konstaterbar logisk kategori inden for et revolutions- eller endog partiteoretisk system. Den bliver mulig at erfare og virkeligt eksisterende hos hvert enkelt individ, for så vidt som den relaterer sig til organisation, (kollektiv) praksis.

\section{Om klassebevidsthedens genese}

I hvert fald siden LUKACS har først krisen skullet kunne give proletariatet $o b$ jektiv mulighed for at gennemskue kapitalens naturgroethed, udbytningsforholdet. Lad os starte med at stille os på dette standpunkt. Vi er enige om, at 'objektivt mulig' endnu ikke betyder: indtrædende 'med historisk nødvendighed'. Det kan altså være, at der overhovedet $i k k e$ bliver gennemskuet noget under konjunkturnedgangen. Der bliver ikke gennemskuet, og ejheller hverken oplevet eller handlet alternativt. Gør et konjunkturopsving det nu - omvendt - umuligt at gennemskue udbytningsforholdet? Bestemt ikke. LUKACS' tese er ikke tilstrækkelig. Man kunne nu tænke sig, at spørgsmålet om krisens funktion som leverandør af 'objektiv mulighed' skulle suppleres med kravet om en instans eller ekstern organisation (extern i forhold til fabrikssfæren), som hver gang bemægtiger sig mulighederne i konjunkturen på en sådan måde, at det objektivt mulige bliver subjektivt muligt og til slut empirisk konstaterbart. Organisationen skulle så $\mathrm{i}$ opsvingsfaser og i perioder med relativ økonomisk stabilitet fungere som en kollektiv hukommelse. Men denne traditionelle tese ville være en forhastet løsning på vort lille dilemma.

6. Jfr. MERLEAU-PONTY, Phämenologie der Wahrnehmung, Berlin, 1966.

7. i ordets emfatiske betydning. Efter at vi nu har diskuteret, hvad »bevidsthed « betyder og ikke skal betyde, bruger vi for korthedens skyld begrebet ubekymret i det følgende. 
Det er rigtigt, at krisen truer de resultater, som arbejderen har tilkæmpet sig, og at han oplever denne trussel mod sin levestandard i sammenhæng med klasseerindringen om epoker med elendighed og arbejdsløshed. Det er også rigtigt, at en mangfoldighed af betingelser, der virker ind på ham, kan gennemtvinge en afspaltning af det, han oplever, fra de mulige erfarings- og handlingsalternativer ${ }^{8}$; tilbage bliver så en nedtrykkende sammenfletning af afmagt og truethed ${ }^{9}$. Imidlertid: der er en mulighed for, at arbejdere (og funktionærer) under konjunkturnedgangen f.eks. gennemskuer grænsen for den »retfærdige løn « og visse garantier for overenskomstautonomien; begge dele udtrykker helt sikkert et moment af klassebevidsthed. Vi gemmer nu et $\varnothing j$ jeblik vor mere grundlæggende kritik af LUKACS' tese og forfølger i stedet spørgsmål om klassebevidsthedens genese.

Til den netop diskuterede mulige kilde til klassebevidsthed kommer en anden af lige så stor betydning. Når kapitalen gennem teknologiske spring yderligere opdeler komplekse arbejdsfunktioner i simple, når den arbejdsorganisatoriske optimering af produktionsprocessen betyder dekvalificering, når der indføres nye arbejdsvurderingsmetoder og arbejdstempoet øges, er der også noget, der bliver truet. Det er ganske vist ikke sikkerheden med hensyn til at have en arbejdsplads, ejheller den $\varnothing$ konomiske standard, ikke i første række i hvert fald. Men derimod den rest, der endnu er tilbage, indenfor éns arbejdsfunktion, af konkret og indholdsfyldt tid, - stadig kun lidt, men dog alligevel tilstrækkeligt til, at virksomhedsloyalitet og arbejdsmoral bevares; muligheden for at overvinde sin udmattelse i pauser og fritid, for de overleverede former for reproduktion af arbejdskraften kan ikke længere kompensere for de ændrede psykofysiske belastninger på arbejdspladsen; den rest af selvfølelse og kollegialitet, der stadig kunne udvikle sig i de minimale spillerum, som arbejdsorganiseringen gav, og som nu truer med at svinde bort - i og med intensiveringen af arbejdet og kontrollen. Til dette føjer vi: »rationaliseringer « åbner en 'objektiv mulighed' for, at arbejdere endnu engang mærker, i hvor høj grad enhver form for beslutningsmyndighed (over deres arbejde) er frataget dem, de berøves de simpleste borgerlige rettigheder, de fratages ligesom deres samfundsmæssighed..$^{10}$ Hvad »erkendes « der så i disse faser? Nødvendigheden af at sætte sig imod kapitalens abstrakte

8. Forholdsregler fra kapitalens side som: afskedigelser, trussel om eller faktisk nedskæring af arbejdstiden som midler i borgerskabets politiske kamp; eksistensen af 'gæstearbejdere' eller en industriel reservearmé; fagforeningernes og arbejderpartiernes politik, når de f.eks. omfortolker arbejdernes kampberedskab til rene lønstrejker.

9. en sammenfletning, der tit og ofte udløser konservative holdninger.

10. Denne umyndiggørelse af arbejderen, hans udelukkelse på alle planer fra de steder, hvor der bliver truffet samfundsmæssigt betydningsfulde afgørelser. blev i øvrigt tematiseret meget mindre i den klassiske tyske arbejderbevægelse end andre former for udbytning og undertrykkelse.

11. Jfr. LIP-arbejderne (Frankrig): tiden som den vare, hvori alle andre varer fremstilles. »Vi vil have, at alle skal lære at rette sig efter solen«. I: J.P. Lallement, Projektgruppe Gegengesellschaft, Düsseldorf, 1974. 
tid $^{11}$; nødvendigheden af at bekæmpe den hierarkiske arbejdsdeling, der på én gang skal maximere både arbejderens ydelse $o g$ borgerskabets fuldmagt til at lede og fordele. Som handlingsalternativer opstår der nye kampteknikker, der retter sig mod selve kontinuiteten i produktionen; på grundlag af disse kan der opstå behov for selv at overtage produktionen (uden først længe at spørge fagforeninger eller parti) ${ }^{12}$

Her drejer det sig helt sikkert om væsentlige momenter af klassebevidsthed, om noget stofligt. Omend den rene intensivering af arbejdet gennem forøgelse af arbejdstempoet ikke er bundet til investeringer i de pågældende brancher, så gælder dette dog for teknologiske spring, rationaliseringer, omorganiseringer af arbejdet, og tidsstudieanalyser, og dermed er disse ting i det mindste ikke bundet til konjunkturnedgangen. (I øvrigt får borgerskabets krisespecifikke forholdsregler deres særlige, klassespecifikke kontinuitet $\mathrm{i}$ arbejdernes erfaringer.) Vi kunne også udtrykke dette andet genetiske (og stoflige) moment ved klassebevidstheden således: der dannes en erfaring, der er relativt uafhængig af krisecyklen, om en repressionssammenhæng, der udspiller sig bag konjunkturcyklen som den empiriske side af værdiabstraktionen, dvs. arbejdets realitet under kapitalismen. Her dannes en erfarings-horisont for en politisk bevidsthed hos arbejdere (og andre lønafhængige $)^{13}$.

Spørgsmålet om klassebevidsthedens genese må suppleres med et tredje moment. Ved reguleringen af statens investeringsaktivitet - delvis ved at enkelte kapitalejere eller koncerner lægger pres på kommunernes politisksociale og økonomiske beslutninger - opstår der i bybefolkningens hverdag (ofte også i bøndernes) hele områder, hvor behovene ikke længere dækkes, og mangeloplevelser bliver hyppige: bolig, kvarter, nærtrafik, skole ${ }^{14}$. I de senere år er der opstået nye områder for $\varnothing j$ nene af os, hvor der udvikler sig kritiske potentialer: f.eks. inden for sundhedssektoren, hvor det, at bestemte isolerede sektorer inden for medicinen er højt- eller overudviklede, producerer brede områder med utilstrækkelig lægelig forsorg for befolkningen. I storbyerne fortsætter opløsningen og tømningen af centrerne i stadigt voksende fart - med de konsekvenser, det har i form af stigende kriminalitet og forfald i den bymæssige kommunikation. ${ }^{15}$

Disse former for underudvikling, som kapitalismen producerer, forener sig med arbejdsgivernes såkaldte tilegnelsesstrategier, som går ud på at bemægtige sig befolkningens følelser, drømme og behov. ${ }^{16}$ Udbredelsen af massekommunikationen

12. Den teknik at afbryde produktionens kontinuitet (og tilfælde af sabotage) minder mange om maskinstormen i det 18. og 19. årh. Det drejer sig imidlertid om begivenheder, der er genetisk forskellige, og som politisk må vurderes forskelligt.

13. Vi abstraherer påny fra yderligere eksterne betingelser, jfr. note 8 .

14. I BRD udøves dette pres på kommunerne via beskatningen af erhvervslivet, som kommunerne i vidt omfang er blevet afhængige af.

15. Jfr. P. Brückner/A. Krovoza: Staatsfeinde. Wagenbach, Politik 40, Berlin, 1972, kap. IV (s. 72 ff.).

16. Jfr. O. Negt/A. Kluge, Öffentlichkeit und Erfahrung, Frankfurt, 1973. Offentlighet og Erfaring, GMT 1974. 
har næsten opløst de tilbageblevne rester af overleveret klassekultur blandt arbejderne. Alle disse former for ekspropriation besvarer borgerskabet med mottoet »mere livskvalitet!«, mens de inden for socialrevolutionære bevægelser begribes som indre kolonisation.

Sammenfattende: Vi kan allerede ud fra en empirisk betragtning se, at den 'objektive mulighed' for klassebevidsthedens opståen ikke kan bindes til konjunkturcyklen, ikke engang til fabrikken. Dette burde imidlertid heller ikke ske. Politisk bevidsthed $i$ sammenhoeng med konjunkturcyklen er langt snarere og $i$ egentlig forstand kapitalistklassens sag. For den fremtræder produktionen som afhængig af markedet, og alle forandringer, brud, katastrofer i markedssfæren påkalder sig derfor nødvendigvis dens levende interesse. Kapitalister planlægger, føler, tænker indenfor rammerne af konjunkturen. Hvad de end producerer - markedet afgør om de har succés. Det er borgerskabets hic rhodos. Borgerskabets klassebevidsthed hænger uløseligt sammen med konjunkturen - både som selvbevidsthed og som kampberedt handlen, som handlen mod konkurrencen og mod proletariatet på arbejdsmarkedet. Men det, som gælder for borgerskabet, behøver ikke uden videre også gælde for proletariatet. Naturligvis har proletariatet som klasse i det borgerlige samfund også positivt-identificerende del i samfundets skæbne. For så vidt som denne skæbne bliver bestemt af den herskende klasse (dvs. af kapitalakkumulationen), er proletariatet også tvunget til at have del i den borgerlige bevidsthed. For så vidt kan dets politiske eller samfundsmæssige bevidsthed følge begivenhederne på markedet.

Men netop kun så vidt. Arbejdernes politiske bevidsthed skal vi hellere søge i $\varnothing$ konomiens sfære, i produktionen: væk fra den borgerlige forblændelsessammenhæng, 'markedet' til det potentielt socialistiske kommunikationssted, fabrik$\operatorname{ken}^{17}$. Proletariatets politiske bevidsthed som en specifik produktionsbevidsthed. Dvs.: arbejdere erfarer udbytningen. De kan opnå en bevidsthed om, at årsagerne til kriserne er denne udbytning og ikke disproportionerne på markederne. Profitkriteriet, som kapitalejerne og deres direktører forvalter $\varnothing$ konomien på grundlag af, er irrationelt, set i forhold til forsyningen af samfundet, og bør afløses af behovskriterier, der kun kan udvikles kollektivt. Men i grunden er denne »bevidsthed « mere en viden, en indsigt - altså mindre end det, som vi forstår ved klassebevidsthed. Denne kritiske proletariske »konjunktur«-bevidsthed kan højst ledsage en politisk omstrukturering af, hvordan der erfares, tænkes, føles og handles.

Det væsentlige i forholdet mellem de lønafhængiges klassebevidsthed og konjunkturcyklen er, at den - i modsætning til borgerskabets - løser sig fra cyklen.

17. Det har LUKACS også gjort. Men i hans formel: Klassebevidsthed »er den rationelt afvejede reaktion, som tilordnes bestemte situationer i produktionsprocessen «, falder den idealistiske kantianer tilbage til positivistiske opfattelser. (Kilde: Klassenbewusstsein, i: Kommunismus, 1920, bd. 1, s. 130 ff. Cit. efter Marxismus Archiv, bd. 1, makol Verlag, Frankfurt, 1971). 


\section{Klassebevidsthed og organisation}

MARX spørger: Hvordan kan den borgerligt-filosofiske idé om den »verdensskabende subjektivitet « omformes materialistisk? Siden teserne om FEUERBACH har vi kendt svaret: Det materialistiske begreb for 'verdensskabende subjektivitet' er begrebet praksis.

Praksis er en kollektiv handlen, der er rettet mod forandring af det bestående. Den kritiske teori, som forkaster, fordømmer det bestående i dets tilblivelseshistories kontext, er selv et moment af 'praksis' ${ }^{18}$. Forsåvidt som det bestående må defineres som produkt, som fremtrædelse for værdiabstraktionen, forkaster den kritiske teoritiske teori det bestående i deres navn, hvis bestemmelse over deres arbejde, over deres liv er blevet dem fravristet. Denne praksis, kollektiv, forandrende handlen, kan vi fra dens subjektivt-praktiske side bestemme som »klassebevidsthed «. Men en sådan bestemmelse ville forblive abstrakt, fordi den ikke osse samtidig siger, at kollektiv handlen nødvendigvis frembringer former for denne handlen, der ikke kan begribes som blot naturgroede. Denne handlen slider sig jo op på en bestemt modstander og har et »brugsværdi«-agtigt og historisk moment mere end kun den reaktion, der skulle tilordnes den ifølge LUKACS (se ovenfor). De former, som den producerer, er i første omgang endnu ikke virkelig dens egne, men de må - af grunde der skal nævnes senere - ikke gælde fx som blotte betingelser for kollektive kampes effektivitet, deres betydning er solidaritet. ${ }^{19}$ Kollektiv handlen skal selv indeholde »begrebslige momenter «, nemlig: dens form, organisation skal sikre, at det revolutionære postulat om enheden af teoretisk kritik og forandrende handlen antager objektiv sandhed - den skal også kritisere det bestånde praktisk.

Vi må bestemme organisation dobbelt: For det første ud fra aspektet formidling af teori og praksis. Deres enhed skal etableres i processen af organiserede kampe. Hver enkelt empirisk bevidsthed (eller subjektivitet) må gennemgå denne proces ${ }^{20}$. For det andet bestemmes organisation ud fra aspektet anticipation af »frihedens rige « $\mathrm{i}$ kampenes former. Forsåvidt står vi endnu ganske tæt ved den tidlige LUKACS. Hvad betyder det for en proletarisk organisation? Anticipationen sigter mod en tilstand, hvor hver enkelt er solidarisk med hver enkelt af de andre; og dette gælder for forsøget på at tilkæmpe sig bestemmelsen over ens egne arbejds- og livssammenhænge. Vi kan godt betegne dette: sammenfletningen af solidaritet og autonomi, som »klassebevidsthed «.

18. og løser sig dermed fra det »forhistoriske« herredømme af naturlige elementer i de historiske forandringer af det bestående.

19. Også kampenes form, organisation må altså tilegnes, jvf. nedenfor.

20. Først da bliver organiseret handlen til erkendelsesmetode: fordi vi erkender, idet vi forandrer; til metode for forandringen selv; og til en metode for selvforandring (og selvindsigt). Det, som (endnu) betinger os, og det, som vi selv kan være, forandrer vi på én gang. 
En historisk ulykke bringer os imidlertid langt væk fra LUKACS. I »Geschichte und Klassenbewusstsein « ser han - under aspektet enheden af teori og praksis - organisationen således: Det er kun en organisation af den kæmpende klasse, partiet, som haler den materialistiske teori op fra den blot subjektive menings niveau og som med den politiske sandheds objektivitet gør teorien forpligtende. ${ }^{21}$ Partiet skal osse sikre, at klassens kamp bliver en »kollektiv « kamp: det skal bringe den påståede kaotiske mangfoldighed af ikkeorganiserede (eller svagt organiserede) kampe på en kollektiv klassepraksis’ enhed. Klassebevidstheden legemliggøres altså i partiet. »Stadig mere stormende«, håber LUKACS, vil arbejdermassen strømme til partiet og dermed i retning »af dens egen bevidstgørelse«. Også for ham foretager partiet det første bevidste skridt henimod »frihedens rige« (= løser altså problemet med anticipationen, se ovenfor). Hvad betyder det? For LUKACS bliver »klassebevidsthed « ikke empirisk, virkelig i arbejderne, ikke i klassen, men derimod i en adskilt organisation, i partiet - i sidste instans i partiledelsen.

Hvad bliver der da af »enheden af teori og praksis«? I arbejderpartierne regnes historiens subjekt for allerede garanteret, teorien forefindes, den er allerede skrevet. Historiske detaljer, siger J.P. SARTRE, som kunne relativere dogmet om den »forefundne teori«, som kunne nødsage os til at gennemprøve vores begrebslige inventarium, bliver afskaffet som om de var agenter for kontrarevolutionen. Til syvende og sidst bliver teori blot en legitimeringsideologi.

Standardisering af kampene: her hersker altså antagelsen af en »kaotisk mangfoldighed «, som skal ordnes og tilskæres af partiledelsen. Hvor kommer det »kaotiske« fra? For en stor del fra organisationsfornuftens skemaer. Hvis historiens subjekt først har personificeret sig i partiet, så bliver decentrerede, autonome kampes mangfoldighed kaotisk. Indholdet har altid tabt på forhånd. Ethvert individ som afslår at følge en partibeslutning regnes for et blindt agerende subjekt, altså i det hele taget enhver kæmper uden for organisationen, »Klassebevidsthed «: herindi bliver der nu istedet for solidaritet sat disciplin, hvis praktiske formål er at give partiet chance for at råde over de organiseredes handlen og bevidsthed ${ }^{22}$. Formelt forbliver partiet det første bevidste skridt henimod »frihedens rige $\ll^{23}$. Men indholdsmæssigt er det, allerede ifølge LUKACS, disciplin, centralisation, hierarki, som anticiperer det. Strengt kantiansk bliver klassebevidsthed til over-jeg, til inderliggjort herredømme: til udtryk for en handlen, som retter sig efter en pligt, ikke længere efter en tilhøjelighed, som

21. Jvf. hertil H.-J. KRAHL, i »Geschichte und Klassenbewusstsein heute«, se note 2.

22. Det hører til den kapitalistiske kommandostrukturs væsen, at bourgeoisiet organiserer arbejdet således, at både arbejderens ydelse og dets egen kontrolkapacitet maximeres, se ovenfor.

23. Spontanitet, som den på én gang giver sig udtryk som led i arbejdskampe anses for en udadvenden (»Entäusserung «) af en kapitalistisk produceret. Arbejderne er følgelig virkelig variabel kapital, jvf. senere. 
retter sig efter organisationens praksis, ikke længere efter brugsværdiorienterede behov. Organisationen orienterer sig dermed mod fabrikkens kommandostruktur og organisation ${ }^{24}$.

Vi talte om en »historisk ulykke«. Den lader sig nu beskrive således: Klassebevidstheden skilles fra klassens enkelte empiriske subjekter. Den abstraherer fra dem. Der opstod historisk et brud - og det opstår igen og igen idag - mellem de virkelige enkelte individer, hvis aktive samfundsmæssige handlen jo alene kan betyde en historisk omvæltning, og så denne »subjektivitet«, der ikke skal have personificeret sig praktisk i klassen, men derimod »rent « i partiet. Dette brud gøres ukendeligt gennem formelen om partiet som arbejderklassens »mest bevidste fraktion«. (Jvf. hertil vores Anmarkninger, s. 169).

I partiteorien blev klassebevidsthed og kapitalbevægelse iøvrigt sat i forhold til hinanden på en måde, således at organisationen, dvs. arbejderpartiet, fremtrådte som $n \phi d v e n d i g$ for dannelsen af en revolutionær bevidsthed, der transcenderede kapitalismen. På virksomheden kunne og skulle arbejderen kun opbygge og adlyde, som et stykke variabel kapital var han her dømt til at bekræfte kapitalismen. Kun uden for arbejdet, i forsamlinger, demonstrationer, når alt kommer til alt som valger, kunne han vise sig som revolutionær, kunne han erhverve sig og bevise klassebevidsthed. Denne opfattelse af den rå, ikke partioplyste proletariske bevidstheds afhængighed af det borgerlige skin og af kapitalens cyklicitet opstod i løbet af socialdemokratiets strid med fagforeningerne. (I Rusland fandt den samme proces sted mens mensjevikkerne og bolsjevikkerne udviklede sig væk fra hinanden). Idet partiet søgte at erhverve sig kontrollen over for fagforeningerne, måtte det frakende dem - og dermed hele det umiddelbare fabriksarbejdes sfære - revolutionære muligheder. Dertil hørte definitionen af lønkampen og videre af »dagskampen«, af den »økonomiske kamp«, af »fabrikskampen « som immanent, reformistisk, integrativ. Økonomisk kamp er nødvendig for at kapitalen indrømmer arbejderen hans existensminimum (den lassallske »jernhårde lønningslovs« fortsatte virkning i socialdemokratiet helt frem til folk som Rosa Luxemburg), men denne kamp og den bevidsthed, som den formidler, kan aldrig føre ud over kapitalismen. Forholdet mellem klassebevidsthed og kapitalbevægelse blev altså indbygget i partiets legitimeringsideologi.

Denne eksternalisering af klassebevidstheden, dens fæstnelse til en særlig organisation, dens fjernen sig fra den forhåndenværende, virkelige bevidsthed, også der, hvor denne massivt finder sit prægnante udtryk i kampe, er uløselig fra positiviseringen af Marx' »kritiske teori« til en lare og fra padagogiseringen af alle relationer mellem partiledere og medlemmer, af hele det arbejderpolitiske klima. Proletaren, hhv. hans »klassebevidsthed « skal optage og bekræfte noget allerede færdigt, rigtigt (den marxske »lære«, partiets taktik); den »hensynslø-

24. Med hensyn til de såkaldte vestlige industrinationer, som er ramt af de borgerlige samværsformers selvødelæggelse: redder partiet så ikke borgerlig arbejdsmoral, etik osv.? 
se kritik af alt bestående« som det marxske værks »ånd « existerer allerede, er ovenikøbet organiseret, tvivl, kritik, forandring forstyrrer nu kun. ${ }^{25}$ »Proletariatets bevidsthed « var i II. Internationales blomstringstid et kar, som skulle fyldes med marxisme, partidoktrin og tro på det endelige mål.

Der gjorde sig altså et udelukkende receptivt bevidsthedsbegreb gældende, intet virksomt begreb, der var formidlet og formidlende til egen erfaring. Man kan sige, at partierne yderligere har eksproprieret proletariatets autonome kampe og dermed en bevidsthed, som proletariatet kunne og kan ska be i dets daglige sammenstød med mestre, kapitalister, boligudlejere, osv. kort sagt med udbytning og herredømme som kan erfares og erfares på éns egen krop. »Udbytning « skulle kun i teoretiseret og abstraktificeret form være værdig til at blive til et bevidsthedsindhold hos proletariatet. »Autonome« indsigter, kampe, modværge, alternativer var meget ilde set, enhver tanke, der modsatte sig den revolutionære centralisering, var forbudt. Dette var altsammen en nødvendig konsekvens af partiernes programmatik, af deres politiske aktioner med det mål at erobre statsmagten, dvs. en abstrakt form for samfundsmæssig magt.

»Socialdemokratiet skærer (altså) den negative side af produktionsforholdet (arbejderen som modsætning til kapitalen eller hans fremmedgørelse fra produktet) ud som en fremtidsopgave (at tilintetgøre kapitalismen), som alene skal varetages politisk af socialdemokratiet selv, og overlader arbejderen den positive side som den nutidsopgave, som skal udføres $\varnothing$ konomisk af ham: at producere kapital. Ikke blot tidsligt-taktisk, men osse indholdsmæssigt-programmatisk løser socialdemokratiet den revolutionære handling at ophæve lønsystemet fra klassekampen som kapitalforholdets hverdag og gør denne handling til sit eksklusive område - det fixerer dermed proletariatet i dets daglige lønarbejds-åg på en ikke blot ikke-revolutionær, men ovenikøbet systemopretholdende virksomhed. Det adskiller praktisk-institutionelt den positive produktion fra produktionen af sprængkraft inden for kapitalforholdet.

Benægtelsen løsses fra arbejdsprocessen og træder som sagens positive sjæl over i partiinstanserne. ${ }^{26}$

Når v i idag spørger efter adækvate organisationsformer, så kan vi gå ud fra de kvaliteter (autonomi, emancipation), den praksisberedskab, de anticipatoriske programmer og fors $\varnothing \mathrm{g}$, som vi ovenfor har nævnt som konstituerende for klassebevidsthed. Hvor disse kvaliteter er blevet mulige: i nye strejkeformer, ved fabriks- og husbesættelser, i dele af kvindebevægelsen, i studenterbevægelsen, hos bønderne i Larzac ${ }^{27}$, dér har vi åbenbart at gøre med adckvvate organisationsformer. Ganske kort kunne man betegne disse former som decentrale, indholds- hhv. projektorienterede, autonome og åbne for indbyrdes udveksling og kommunikation. Det drejer sig idag ikke længere kun om de afhængige og udefra definerede menneskers tilegnelse

25. LUKACS påtaler hos dogmatisme-kritikerne den »tvivlesyge, der er udhulet og fortæret indefra«.

26. fra: Schwarze Protokolle Nr. 2, Rosa Luxemburg-Kritik, s. 46, Berlin, 1972.

27. Jvf. $\mathrm{i} »$ Ästhetik und Kommunikation« nr. 17 artiklen af Lothar Baier. I løbet af de sidste fire år fandt franske bønder i Larzac sammen for at forhindre, at deres græsjord blev forvandlet til en troppeøvelsesplads (udvidelse af en existerende plads). 


\title{
af livs- og arbejdsbetingelser, men samtidig om en gentilegnelse af kampen for disse betingelser.
}

\author{
Anmærkning til »Klassebevidsthed og organisation«
}

Hvilket konkret social proces betegner dette »brud«, som er opstået historisk? (s. xx). I hvilke sociale brydninger og med hvilket formål har partiernes organisationsdisciplin dannet sig, som således har abstraheret fra de arbejdendes empiriske existens? Vi må også betragte organisationen »parti« og »organisationsfornuftens skemaer« som specifikke svar på socioøkonomiske omvæltningsprocesser, som del af et kollektivt løsningsfors $\emptyset \mathrm{g}$ for disse omvæltningers problemer.

(1) Det 19. og det begyndende 20. årh.'s arbejderpartier, som LUKACS har legitimeret og som var blevet politisk hjemsted for store dele af det europæiske proletariat, virkede, således som de selv forstod det, på »fremskridtets « side, og det ville sige: for en fremskyndelse hhv. forberedelse af industrialiseringen og mod bornert småproduktion i landbrug og håndværk. Kapitalakkumulationen skulle i den fase, hvor vareproduktionen og den tekniske lettelse af arbejdet endelig voksede hurtigt - foregå krisefrit og centralt ledet; den skulle unddrages det ødelæggende konkurrerende bourgeoisis dispositionsret. Kategorien den »kaotiske mangfoldighed « svarede i Ruslands daværende sociale virkelighed til den store, ukontrollerbart producerende masse af bønder hhv. til den agrarsocialiserede arbejder, der ved høsttid forsvinder ud til landsbyen. Heller ikke i vesten kunne proletariatet dog uden videre tilpasses til kapitalistisk rationalitet - her hjalp arbejderpartierne i fornuftens, ateismens og vareproduktionens navn. Hverken de gamle socialdemokrater i Tyskland eller kommunisterne adskilte den objektive koncentration af produktionssteder til store industrikomplexer fra magtkoncentrationen i hænderne på produktionsprocessens ledere, magtkoncentrationen over arbejdermasserne, dvs. fra kapitalens kommandostruktur (hierarkiet i fabrikken). Begge dele gik sammen for dem, og det forekom dem kun muligt at »ophæve« sidstnævnte forhold ved at udskifte de borgerlige kapitalister og managere med socialistiske funktionære og ledere. Organisationen »parti«, som skulle forberede magtovertagelsen, var dannet analogt til dette program.

(2) Arbejderpartierne virkede imidlertid også for den sociale integration, dvs. for standardiseringen og stabiliseringen af den masse-befolkning, der hurtigt opstod i den 2. halvdel af det 19. årh. Som alle nationalstatens og den kulturelle integrations institutioner fandt SPD såvel som fagforeninger langt hen deres »modstandere« uden for »klassefjenden«, (stor-)bourgeoisiet: i de subkulturer af bonde- og håndværksmæssig struktur, der endnu bestod, i de småborgerlige lag, for så vidt som disse stod under indflydelse af stands- eller hjemstavnsideologier, altså ydede modstand mod industrialiseringen og den sociale integration, i de udbredte forekomster af rodløshed i storbyerne (lige til den $\emptyset$ konomiske og/eller sociale elendigheds alkoholisme). Vi vil minde om, at Salpétriere i Paris omkring 1880 blev oversvømmet af patienter med hysteri og andre psykisknervøse forstyrrelser, patienter, som overvejende tilhørte laget af exproprierede bønder og småhåndværkere; de erhvervede sig dermed adkomst til at bruge de nye forsorgsindretninger, som stat eller kommune havde indrettet. Industrialisering, social og kulturel integration af den nye massebefolkning og den institutionelle reaktion på udgiftssiden, folkevelfærden, er altså de historiske omvæltningsprocesser, som der måtte søges og findes et kollektivt svar på. Selvom organisatorerne og deres teoretikere muligvis har forestillet sig det anderledes, hører »organisationsfornuftens skemaer« samt partiernes hierarkisk-disciplinerede struktur med i dette svar. 


\section{Slutning:}

Klassebevidsthed er en praktisk sag. Dens mål er positivt bestemt en organisering af arbejdet, som er orienteret efter menneskelige rytmer og ikke kun maskinelle takter, en opløsning af de hierarkiske strukturer på fabrikken og endelig tilegnelse af beslutningsmyndigheden over produktion og fordeling. Begivenheder, hvor en sådan klassebevidsthed har været virksom: »vilde « strejker og fabriksbesættelser i Italien, Frankrig, England og Tyskland (BRD), altså kampe, hvor det hele tiden har drejet sig om råderetten over produktionens kontinuitet, om menneskeliggørelse af arbejdet, om proletariatets autonomi, men også protestbevægelser blandt bønder, lærlinge, hjemmearbejdersker, taler for en langsomt fremadskridende autonom proces, hvor de lønafhængige selv konstituerer sig som klasse. ${ }^{28}$ Disse begivenheder og deres former har frigjort sig fra kapitalens cykliske bevægelser (og fra partierne). De lønafhængige begynder igen at tilegne sig deres kampe.

Klassebevidsthed er ikke blot et praktisk, men også et smukt og dristigt begreb, fordi det har proceskarakter: det vil vise sig, det eksisterer ikke simpelthen empirisk konstaterbart. Et dynamisk begreb par excellence. Det beskriver ikke nogen tilstand, men derimod den proces, der konstituerer »klassen« i de aktuelle kampe; dets betydning er autonomi. ${ }^{29}$

Men: Klassebevidsthed er også et klogt begreb, der ikke tillader en opløsning i ren og skar proceskarakter. Var det tilfældet, kunne det ikke gribe en hel række vigtige aspekter i den aktuelle situation, som må beskrives sociologisk og socialpsykologisk.

»Klassebevidsthed « er i sig selv så at sige bundet til det jordiske; »organisation« er derfor ikke en ballast, der hænger ved den, men derimod den form, hvori den socialrevolutionære proces formidles med de givne betingelser.

Klassebevidsthed er endelig et udtryk for, at de arbejdende mennesker ikke kun er produkter af kapitalen. Den, der antager det og venter på den næste krise - den kommer uden tvivl - er ligesom den fulde, der slår armene om en plakatsøjle og løber rundt om den og skriger: »Hjælp, jeg er omringet!«

Oversat af Nina Lykke og Hanne Moller

28. Udtrykket »vilde« strejker er bestemt af de samme tendenser som udtrykket den »kaotiske« mangfoldighed.

29. Hvad ouvrieristiske eller gauchistiske grupperinger i dag forstår ved »kamp« (og hvad vi med studenterbevægelsen i baghovedet betegner som »socialistisk selvoplysnings-proces«, som »dialektik mellem oplysning og aktion«) - processer, hvor det centrale er et moment af praktisk forandring og selv-forandring, anti-kapitalistisk som anti-imperialistisk, omend de ikke længere kontinuerligt kan fortolkes inden for rammerne af »klasse«-begrebet, dette var for de gamle partier noget fremmed, ja: farligt. 